\title{
Е.П. Дулепова*
}

Тихоокеанский научно-исследовательский рыбохозяйственный центр, 690091, г. Владивосток, пер. Шевченко, 4

\section{ДИНАМИКА ПРОДУКЦИОННЫХ ПОКАЗАТЕЛЕЙ ЗООПЛАНКТОНА В СЕВЕРО-ЗАПАДНОЙ ЧАСТИ БЕРИНГОВА МОРЯ В СОВРЕМЕННЫЙ ПЕРИОД}

На основании данных планктонных съемок, проведенных в северо-западной части Берингова моря в 2010-2015 гг., рассчитаны и проанализированы продукционные характеристики зоопланктона для юго-восточной и восточной частей Анадырского залива и наваринского района. В ходе исследования весь зоопланктон был подразделен на 2 трофические группировки - хищный (в основном щетинкочелюстные и гиперииды) и нехищный (копеподы и эвфаузииды). Установлено, что в осенний период (2010-2014 гг.) наблюдалась значительная изменчивость продукционных показателей. Это связано с межгодовой динамикой региональных особенностей размерной, таксономической и трофической структур. Для рассматриваемого периода характерно резкое сокращение в данном регионе биомассы копепод после 2011 г. и значительное уменьшение биомассы эвфаузиид в 2013 г. Все эти особенности динамики копепод и эвфаузиид повлияли на величину продукции зоопланктона. Наиболее высокой продукция нехищного зоопланктона была в 2010-2011 гг. (до $5081 \mathrm{мг} / \mathrm{m}^{3}$ ), наименее - в 2012-2014 гг. (до 2716 мг/м³). Продукция хищного зоопланктона была наиболее значительной в 2013 г. в водах восточной части Анадырского залива, что связано с присутствием здесь Themisto libellula. В целом в северо-западной части Берингова моря в осенний период продуцируется нехищным зоопланктоном от 14,8 до 53,1 млн т, а хищным - от 5,0 до 14,2 млн т.

Ключевые слова: северо-западная часть Берингова моря, динамика зоопланктона, продукция, трофические группировки, скорость оборота биомассы.

Dulepova E.P. Dynamics of zooplankton production parameters in the north-western Bering Sea in the present period // Izv. TINRO. - 2016. — Vol. 187. - P. 187-196.

On the basis of plankton surveys, conducted in the north-western Bering Sea in 20102015 , the production characteristics of zooplankton were calculated and analyzed. Zooplankton was divided into two trophic groups: predatory (mainly chaetognaths and hyperiids) and non-predatory (copepods and euphausiids) zooplankton. Considerable variations of zooplankton production parameters were observed in autumn period. This is due to the inter-annual dynamics of regional patterns of the size, taxonomic and trophic structure of zooplankton. The sharp decline in the copepod biomass after 2011 and the significant reduction in the biomass of euphausiids in 2013 were characteristic for the considered period in this region. All these features of the dynamics of copepods and euphausiids had an influence on the value of zooplankton production. The highest non-predatory zooplankton production was in 2010-2011 (up to $5081 \mathrm{mg} / \mathrm{m}^{3}$ ); the lowest, in 2012-2014 (up to $2716 \mathrm{mg} / \mathrm{m}^{3}$ ). Production of predatory zooplankton was the most significant in 2013 in the waters of the eastern part of the Gulf of

* Дулепова Елена Петровна, доктор биологических наук, заведующая лабораторией, e-mail: elena.dulepova@tinro-center.ru.

Dulepova Elena., D.Sc., head of the laboratory, e-mail: elena.dulepova@tinro-center.ru. 
Anadyr; it was associated with the presence of Themisto libellula. In general, non-predatory zooplankton in the north-western Bering Sea produced from 14.8 to 53.1 million tons during autumn; predatory zooplankton, from 5.0 to 14.2 million tons.

Key words: north-western Bering Sea, dynamics of zooplankton, production, trophic groups, $\mathrm{P} / \mathrm{B}$-ratio.

\section{Введение}

Одним из наиболее высокопродуктивных районов Берингова моря является его северо-западная часть (анадырско-наваринский шельф и свал глубин) (Маркина, Хен, 1990; Сапожников, 1994; Шунтов, Дулепова, 1995; Шунтов, 2001; Дулепова, 2002, 2005; и др.). Результаты многолетних исследований ТИНРО-центра свидетельствуют о большой «привлекательности» именно этой части Берингова моря для нагула планктоноядных рыб (Волков и др., 2007; Шунтов и др., 2010; Волков, 2012а, б; Шунтов, 2016). Здесь в зоне устойчивого антициклонического круговорота и выхода Наваринского течения на шельф Анадырского залива, очевидно, происходит механическое накопление зоопланктона, что благоприятно сказывается на формировании кормовой базы нектона. Именно поэтому данный район является традиционным местом нагула большого количества нектона из восточной части моря (минтай, сельдь, мойва и др.) (Шунтов и др., 1993, 2000; Степаненко, Грицай, 2013).

История исследований пелагических сообществ западной части моря насчитывает более тридцати лет, в течение которых регулярно почти по всем районам этой части моря анализировалось состояние планктона с позиций кормовой обеспеченности рыб (Волков, 1988; Волков, Ефимкин, 1990; Дулепова, 1993; Шунтов и др., 1993; Волков и др., 2007). Как известно, понимание особенностей формирования кормовых ресурсов пелагиали невозможно без знания продукционных характеристик зоопланктона. Ранее (Дулепова, 2005, 2014) были получены материалы о функциональных характеристиках зоопланктона для всей западной части Берингова моря для 2002-2013 гг. В указанных работах была рассчитана продукция зоопланктона в районах западной части Берингова моря для определенных периодов, что в некоторой степени нивелировало межгодовые различия в ее динамике.

Появившаяся в настоящее время новая информация о количественных и качественных характеристиках, а также о суточной удельной продукции массовых видов зоопланктона (Шебанова и др., 2014; Шебанова, 2016) позволяет детально проанализировать изменения, произошедшие в продукционных характеристиках зоопланктона трех районов северо-западной части Берингова моря (юго-восточной и восточной частей Анадырского залива и наваринского района) в 2010-2015 гг. Именно современная оценка продукции с учетом динамики компонентов зоопланктона и является целью настоящей статьи. Результаты расчетов продукционных характеристик зоопланктона дают возможность не только представить объемы вновь образованного зоопланктоном органического вещества, но и понять, с какой скоростью это происходит ежедневно и в течение летне-осеннего сезона. Необходимость проведения такого исследования была вызвана наблюдающейся в последнее время значительной динамикой основных таксономических групп зоопланктона (Волков, 2012а, б) и, соответственно, нестабильностью продукционных показателей зоопланктона в данном регионе.

\section{Материалы и методы}

В основе настоящей статьи лежит информация, полученная при выполнении крупномасштабных комплексных съемок ТИНРО-центра в северо-западной части Берингова моря (район анадырско-наваринского шельфа и свала глубин) в 2010-2014 гг. (осенний период) и в 2015 г. (летний период).

Планктон, как и ранее в экспедициях ТИНРО-центра, облавливался сетью БСД (капроновое сито с ячеей 0,168 мм, площадь входного отверстия $0,1 \mathrm{~m}^{2}$ ) в слое $0-200 \mathrm{M}$ (0-дно, если глубина менее 200 м). Скорость подъема сети составляла 0,7-1,0 м/с. Обработка проб планктона производилась пофракционно в соответствии с методикой, 
принятой в ТИНРО-центре (Рекомендации..., 1984; Волков, 1996). В ее основе лежат: 1 - принцип механического разделения планктонной пробы на размерные фракции (мелкую, среднюю и крупную) и дальнейшей обработки каждой фракции в отдельности классическими или экспресс-методами; 2 - применение для различных групп планктона дифференцированных коэффициентов уловистости; 3 - оценка кормовой базы нектона применительно ко времени суток, подразумевающая расчет параметров по дневным и ночным станциям с учетом миграционных особенностей групп организмов.

При расчетах структурно-функциональных характеристик зоопланктона были использованы ранее применяемые методики анализа трофических характеристик (Дулепова, 2002), позволившие выделить два функциональных элемента - хищный и нехищный зоопланктон. В группировку хищный зоопланктон были включены гиперииды, хетогнаты, полихеты, гребневики и медузы. Эври- и фитофаги (мелкие и крупные копеподы и эвфаузииды) были выделены в группу нехищного зоопланктона. Продукция каждой функциональной группировки рассчитывалась на основе данных о ее качественном составе, соотношении доминирующих видов и сведений об их суточной удельной продукции. Отличительной чертой настоящей работы является использование при расчетах продукции функциональных групп данных о суточной удельной продукции наиболее массовых видов зоопланктона, полученных для различных сезонов конкретно для Берингова моря (Шебанова, 2007, 2016; Чучукало и др., 2013; Шебанова и др., 2014).

\section{Результаты и их обсуждение}

В трех рассматриваемых районах северо-западной части Берингова моря (юговосточная и восточная части Анадырского залива и наваринский район) продукция выделенных трофических группировок зоопланктона на протяжении 2010-2015 гг. значительно различалась (рис. 1). Это связано с межгодовой динамикой региональных особенностей размерной, таксономической и трофической структур в каждом из районов.

Зоопланктон этих районов может быть отнесен к прибрежным и шельфовым сообществам. Основу биомассы зоопланктона (до 92-97 \%) формирует небольшое число видов. Среди них копеподы (Calanus glacialis, Metridia pacifica, Eucalanus bungii, Pseudocalanus newmani, Neocalanus plumchrus, Oithona similis), эвфаузиевые (Thysanoessa raschii, Th. inermis), щетинкочелюстные (Parasagitta elegans) и гиперииды (Themisto libellula, T. pacifica). Копеподы и эвфаузиевые составляют основу группировки нехищного зоопланктона, а представленные виды щетинкочелюстных и гипериид основу хищного зоопланктона.

Согласно проведенным исследованиям с 2010 по 2014 г. в осенний период в северозападной части Берингова моря (анадырско-наваринский шельф) наблюдалась весьма сильная изменчивость количественных показателей зоопланктона: средняя биомасса в этом регионе варьировала от 780 до 1658 мг/м³. При этом наибольшей эта величина

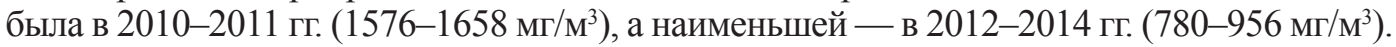
Подобное явление для зоопланктона не считается чем-то из ряда вон выходящим. В биомассе, соотношении видов и групп, а соответственно в количественном распределении зоопланктона, всегда наблюдается значительная межгодовая изменчивость (Шунтов, 2001; Шунтов и др., 2007). Зачастую даже в близко расположенных районах под влиянием океанологических условий ход динамики биомасс значительно различается (рис. 2).

Существенные изменения биомассы зоопланктона, произошедшие в регионе после 2011 г., в основном коснулись юго-восточной части Анадырского залива (3-й район) и наваринского района (5-й район). Здесь общая биомасса зоопланктона в 2012 г. снизилась более чем в 2 раза. Менее значительные изменения были характерны для восточной части залива (4-й район); хотя в отдельные годы (2014) и здесь наблюдалось ее уменьшение.

В этих изменениях были задействованы все без исключения размерные группы зоопланктона (рис. 3), но определяющая роль в динамике биомассы зоопланктона при- 

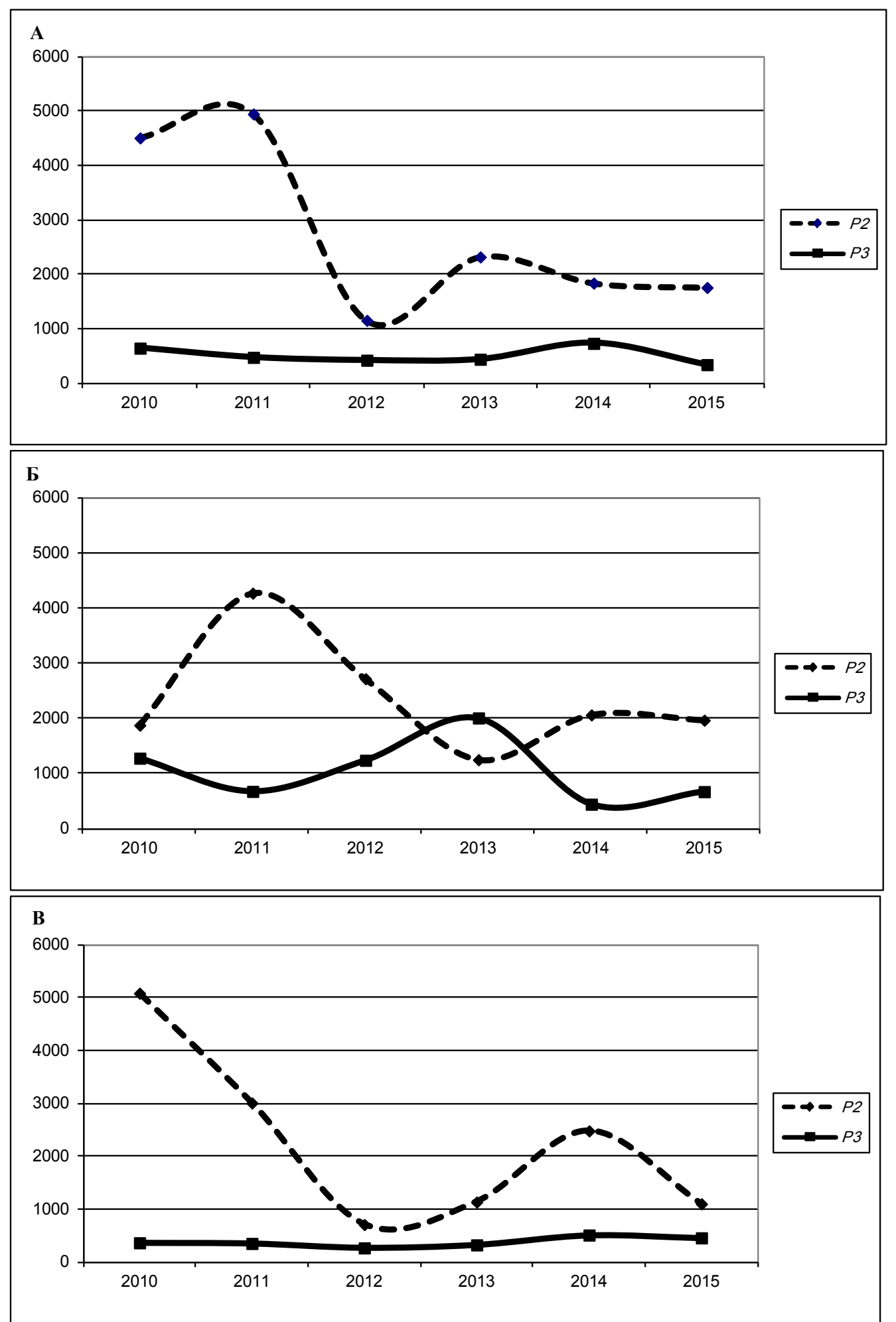

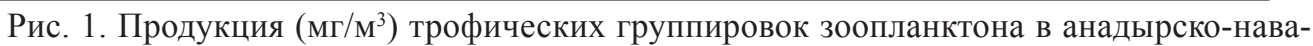
ринском районе: $P 2$ - продукция нехищного зоопланктона; $P 3$ - продукция хищного зоопланктона; A - юго-восточная часть Анадырского залива; $\mathbf{~ - ~ в о с т о ч н а я ~ ч а с т ь ~ А н а д ы р с к о г о ~}$ залива; В - наваринский район

Fig. 1. Dynamics of production of zooplankton trophic groups $\left(\mathrm{mg} / \mathrm{m}^{3}\right)$ in the Anadyr-Navarin area: $P 2$ - production of non-predatory zooplankton; $P 3$ - production of predatory zooplankton; A - south-eastern Gulf of Anadyr; $\mathbf{6}$ - eastern Gulf of Anadyr; B — Navarin area 


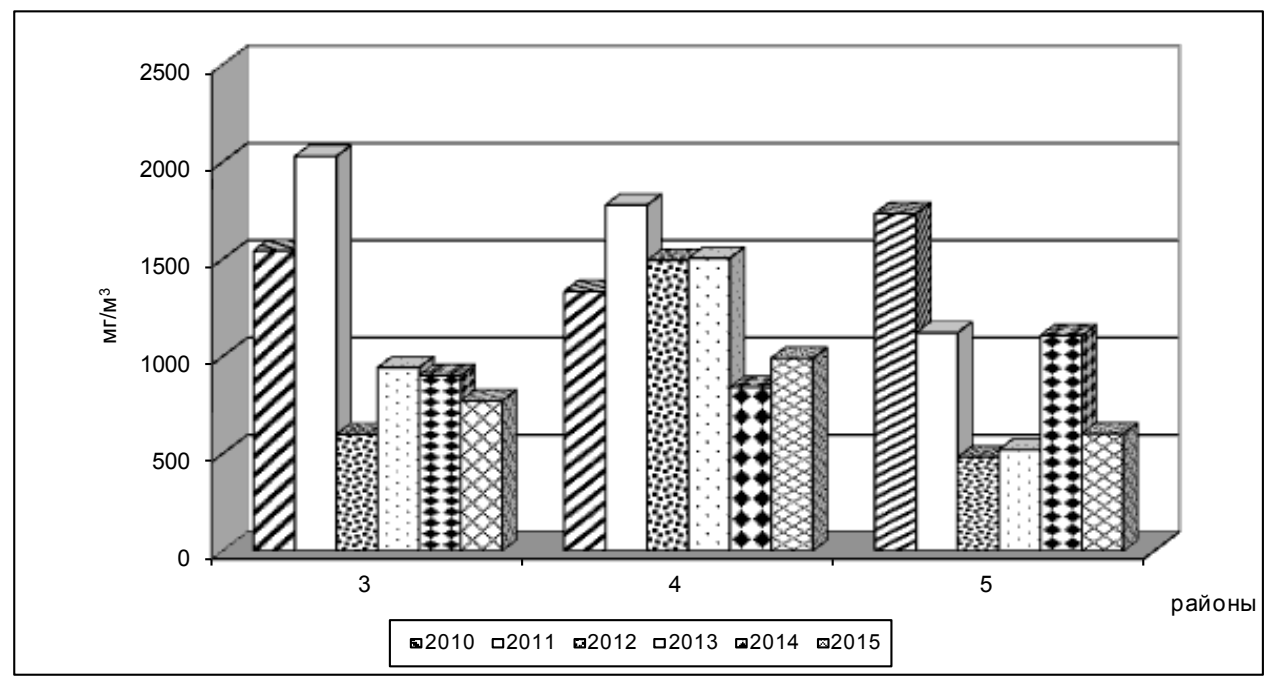

Рис. 2. Динамика биомассы зоопланктона $\left(\right.$ мг $\left./ \mathrm{M}^{3}\right)$ в анадырско-наваринском районе: 3 - юго-восточная часть Анадырского залива; 4 - восточная часть Анадырского залива; 5 - наваринский район*

Fig. 2. Dynamics of zooplankton biomass $\left(\mathrm{mg} / \mathrm{m}^{3}\right)$ in the Anadyr-Navarin area: 3 - southeastern Gulf of Anadyr; 4 - eastern Gulf of Anadyr; 5 - Navarin area
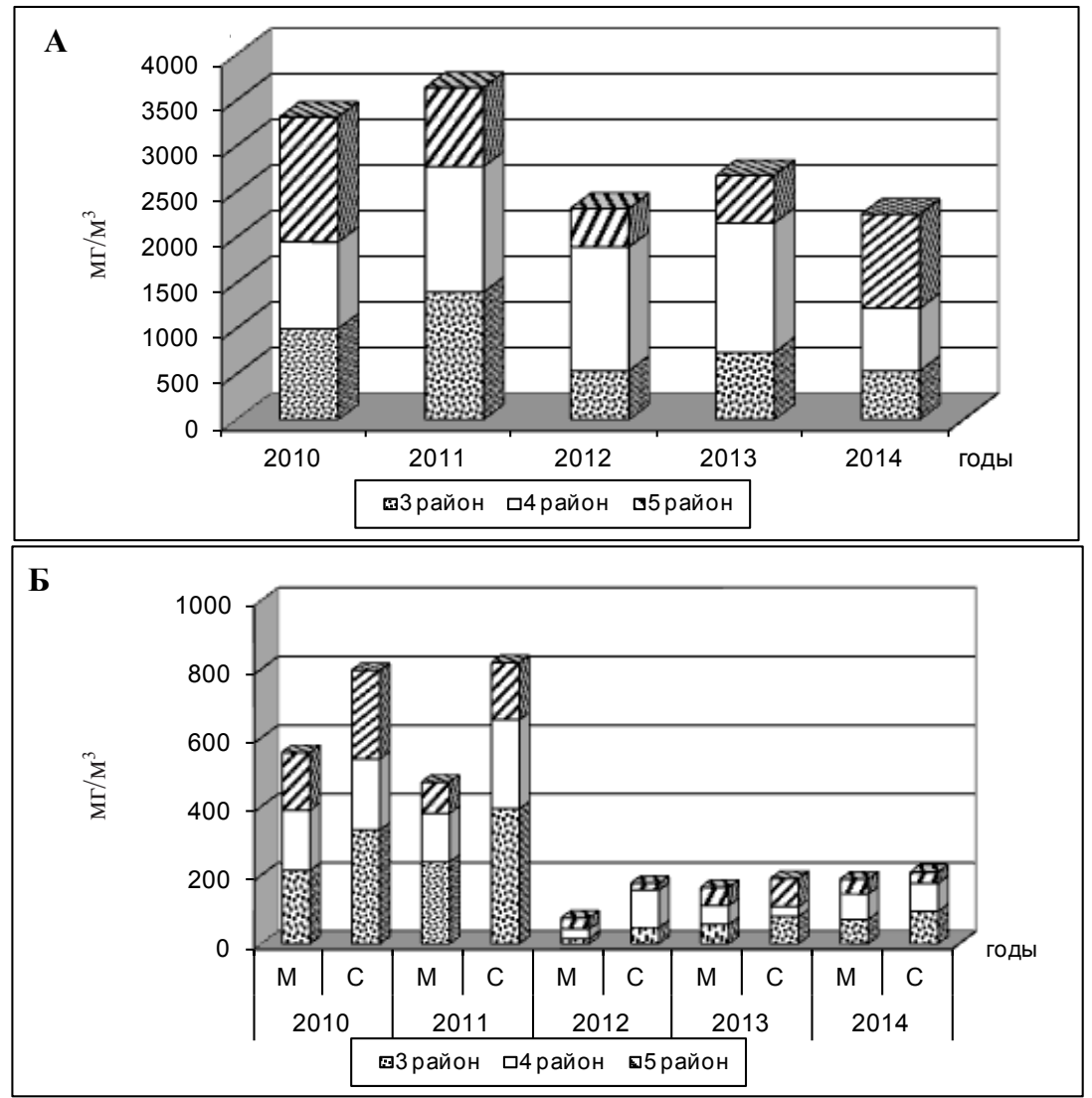

Рис. 3. Динамика биомассы (мг/м³) размерных фракций зоопланктона в анадырско-наваринском районе в осенний период: $\mathbf{A}$ - крупная фракция; $\mathbf{~ - ~ - ~ м е л к а я ~ ( ~})$ и и средняя (c) фракции

Fig. 3. Dynamics of biomass $\left(\mathrm{mg} / \mathrm{m}^{3}\right)$ of zooplankton size groups in the Anadyr-Navarin area in autumn: A -large-sized group; Б - small-sized ( $(\mu)$ and medium-sized (c) groups

* Нумерация районов соответствует ранее принятой для всей западной части Берингова моря (Шунтов, 2001; Волвенко, 2002). 
надлежит макропланктону как основной биомассообразующей размерной группировке и, соответственно, слагающим его таксономическим группам: прежде всего копеподам, в меньшей степени эвфаузиидам, сагиттам и гипериидам.

Наблюдаемое с 2012-2014 гг. снижение биомассы сопровождалось увеличением доли макропланктона (с 70 до 90 \%) и снижением доли зоопланктона с размерами тела менее 3 мм (мелкой и средней фракций).

Анализ динамики основных таксономических групп зоопланктона показал существенные различия в ее развитии для каждой из групп нехищного зоопланктона (рис. 4). Единственное, что наблюдается во всех районах, это одновременное «обвальное» (в 3,9-4,3 раза) снижение биомассы копепод после 2011 г. и дальнейшее весьма небольшое ее увеличение.
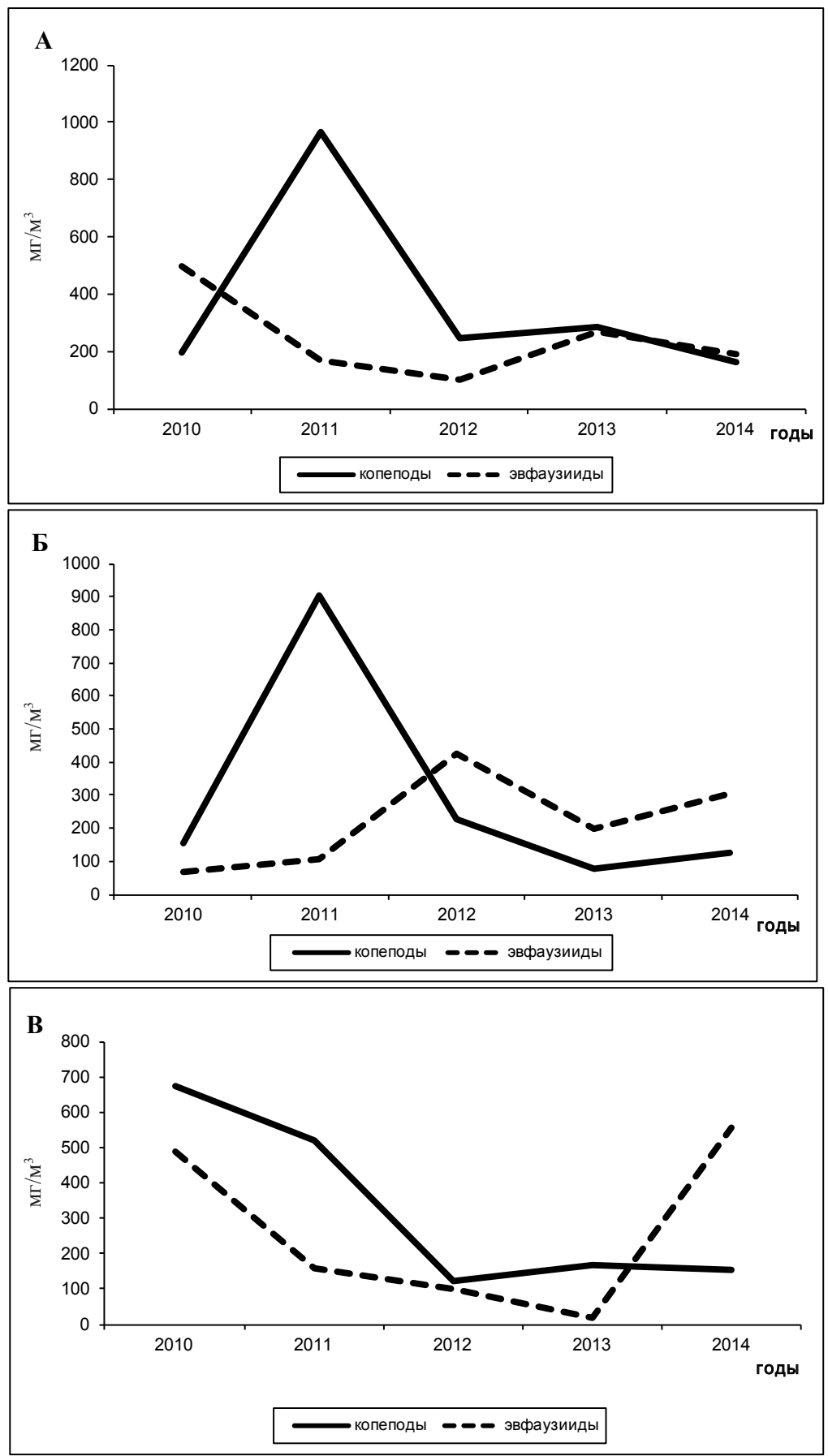

Рис. 4. Динамика биомассы копепод и эвфаузиевых в районах северо-западной части Берингова моря: $\mathbf{A}-$ юго-восточная часть Анадырского залива; Б - восточная часть Анадырского залива; B - наваринский район Fig. 4. Dynamics of the copepod and euphausiid biomass in the areas of the north-western Bering Sea: A - southeastern Gulf of Anadyr; Б - eastern Gulf of Anadyr; B - Navarin area 
Особенностью динамики эвфаузиид в северо-западной части моря является значительное увеличение биомассы (почти в 30 раз) в 2014 г. в наваринском районе после значительного снижения в 2013 г.

Проведенный ретроспективный анализ состава зоопланктона за 1986-2014 гг. позволил также проследить многолетнюю динамику биомассы эвфаузиид наваринского шельфа (рис. 5), т.е. на том участке района исследований, где в 2013 г. отмечалась наименьшая их концентрация.

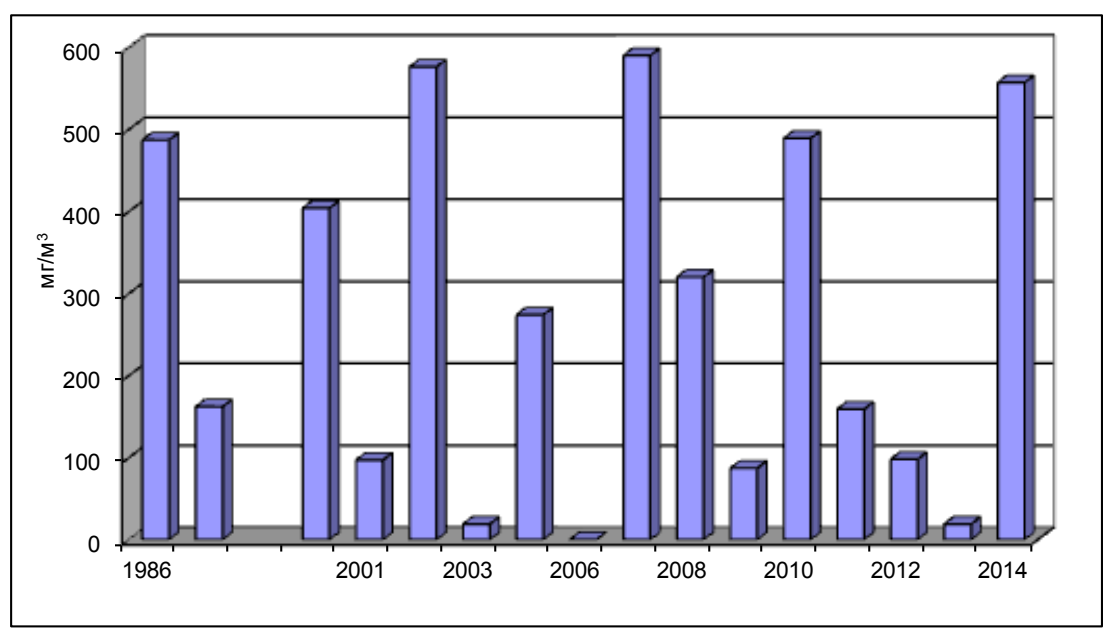

Рис. 5. Динамика биомассы (мг/м³) эвфаузиевых на наваринском шельфе (5-й район)

Fig. 5. Dynamics of euphausiids biomass $\left(\mathrm{mg} / \mathrm{m}^{3}\right)$ in the Navarin shelf $\left(5^{\text {th }}\right.$ area)

Согласно проведенному анализу такое же (как и в 2013 г.) снижение биомассы эвфаузиид в наваринском районе наблюдалось и в некоторые прошлые годы — в 2001, 2003, 2006 и 2009. Причем практически во всех случаях за обвальным снижением биомассы этой группы, сформированной здесь почти исключительно Th. raschii и Th. inermis, следовало не менее резкое (многократное) ее увеличение. Ранее, анализируя динамику биомассы эвфаузиевых в Охотском море, А.Ф. Волков (2002) столкнулся с таким же явлением резкого спада и увеличения биомассы этой группы. Он предположил, что все это связано с сочетанием определенного комплекса факторов, среди которых минимальная ледовитость и минимальная солнечная активность. Несколько позже Э.Л. Орлова с соавторами (2012), тщательно проанализировав динамику нескольких видов эвфаузиид, и в частности Th. inermis и Th. rashii, также пришли к выводу, что эти виды реагируют на изменение теплосодержания в Баренцевом море. Так, $T h$. rashii расширяет свой ареал в аномально холодные годы и сужает до минимума - в аномально теплые. На этом фоне в аномально теплые годы отмечается полное доминирование Th. inermis. Однако, делая этот вывод, вышеуказанные авторы все-таки заключают, что основным регулятором численности эвфаузиид является мойва. Другие исследователи (Dalpadado, Skjoldal, 1991; Дробышева, 1994), столкнувшиеся со сходной динамикой эвфаузиевых, объясняют данный факт исключительно прессом хищников, существенно снижающих биомассу эвфаузиевых за счет выедания. Вполне возможно, что на наваринском шельфе происходит наложение как биоценологического, так и климато-океанологического факторов, влияющих на динамику численности эвфаузиид. Об этом свидетельствуют смена гидрологических режимов (Волков, 2012a, б; Khen et al., 2013) и информация об особенностях питания такого массового потребителя зоопланктона в данном районе, как минтай (Шунтов и др., 1993, 2000; Волков, 2016; Шунтов, 2016).

Все вышеупомянутые особенности динамики копепод и эвфаузиид, формирующих нехищный зоопланктон, безусловно, повлияли на величину продукции (см. рис. 1). Что же касается темпов продуцирования, то формирование единого рассчитанного для трофической группировки Р/В-коэффициента зависит прежде всего от соотноше- 
ния доминирующих в группировке видов. Присутствие в значительных количествах таких высокопродуктивных видов, как M. pacifica и Th. rashii, способно существенно повышать P/В-коэффициент трофической группировки, а отсутствие видов с высоким биопродукционным потенциалом снижает этот показатель. Анализ полученных результатов позволяет заключить, что Р/В-коэффициент в осенний период варьировал от 2,8 до 3,6. Причем наибольшая его величина отмечена для 3-го района в 2010 г. и для 4-го района в 2013 г., наименьшая величина этого показателя наблюдалась исключительно в 3-м районе в 2011 и 2013 гг. В первом случае это было связано с доминированием упомянутых выше M. pacifica и Th. rashii, чьи Р/В-коэффициенты составляли соответственно 5,40 и 4,15 (Шебанова, 2007; Чучукало и др., 2013). Присутствие в нехищном зоопланктоне в значительных количествах в 4-м районе в 2013 г. Th. rashii также способствовало повышению Р/В-коэффициента группировки.

Продукция хищного зоопланктона создается почти исключительно за счет щетинкочелюстных (P. elegans), поэтому именно эта группа и влияет на формирование $\mathrm{P} / \mathrm{B}$-коэффициента. Количество гипериид в хищном зоопланктоне в годы исследований незначительно, за исключением упомянутой выше однократной вспышки численности T. libellula в 4-м районе в 2013 г. Тем не менее наличие представителей этого таксона (особенно T. pacifica, P/В-коэффициент равен 5,36) даже в незначительных количествах способно повлиять на формирование общего Р/В-коэффициента группировки. В целом у хищного зоопланктона на протяжении 6 лет это показатель варьировал в пределах от 1,74 до 2,20 .

Подобный темп продуцирования позволяет создавать нехищным зоопланктерам от 14,8 до 53,1 млн т (или от 164 до 590 тыс. т/сут) органического вещества за осенний сезон, а планктонным хищникам — от 5,0 до 14,2 млн т (или от 55 до 158 тыс. т/сут). В летний период нехищные планктеры создают гораздо больше органического вещества (до 64,8 млн т, или 720 тыс. т/сут).

Сопоставление продукции хищного и нехищного зоопланктона по районам северо-западной части моря показало, что разброс соотношений $\mathrm{P}_{3} / \mathrm{P}_{2}$, характеризующих переход вещества от нехищного зоопланктона к хищному и эффективность функционирования сообщества зоопланктона, весьма значителен (от 0,095 до 1,800 - для осени и от 0,320 до 0,800 - для лета). Превышение продукции хищного зоопланктона над продукцией нехищного (4-й район, 2013 г.) в 1,8 раза свидетельствует либо о привносе планктонных хищников как составной части более зрелых сообществ с других акваторий, либо о недоучете фито- и эврифагов. Подобные результаты получены и для других районов дальневосточных морей (Дулепова, 2002). В то же время по классическим правилам следует, что соотношение $\mathrm{P}_{3} / \mathrm{P}_{2}$ должно быть близко к 0,2 (Одум, 1975; Иванова, 1985). Однако ранее этот коэффициент был получен исключительно для озер и небольших водоемов, где нет перемещения некоторых видов (в частности крупных копепод-эврифагов) в более глубокие слои пелагиали и привноса зоопланктона с других акваторий. В северо-западной части Берингова моря за счет направленного с юго-востока моря Центрально-Беринговоморского течения, которое дивергирует на Наваринское и Восточно-Камчатское течения, создаются предпосылки для постоянного привноса со смежных акваторий и накопления планктона в микроциркуляционных образованиях и на вторичных фронтах (Шунтов, 2016). Однако согласно М.Е. Виноградову (1978) при переносе поверхностных вод течениями населяющее их сообщество становится более зрелым, т.е. в данном случае с более высокой долей планктонных хищников.

\section{Заключение}

Все это, учитывая известные особенности питания хищных зоопланктеров (Fraser, 1969; Косихина, 1982; Дриц, Уткина, 1988) и их способность за счет выедания снижать биомассу нехищного зоопланктона, свидетельствует о том, что в отдельные годы в планктонных сообществах могут наблюдаться процессы дестабилизации и резкого снижения биомассы фито- и эврифагов. Однако приведенные выше оценки продукции свидетельствуют о высоких коэффициентах оборота биомассы (P/В-коэффициенты), 
а следовательно, о быстром восстановлении биомассы нехищных планктеров как кормового ресурса нектона, тем более что в связи с высокой пластичностью питания многих видов нектона его кормовая база помимо нехищного зоопланктона включает в себя планктонных хищников (сагитт и гипериид), мелких рыб и кальмаров, а также личинок донных беспозвоночных (Волков, 2016; Шунтов, 2016).

\section{Список литературы}

Виноградов М.Е. Оценка некоторых функциональных характеристик сообществ океанской пелагиали и их изменчивости // Элементы водных экосистем. - М. : Наука, 1978. - С. 3-18.

Волвенко И.В. Морфометрические характеристики стандартных биостатистических районов для биоценологических исследований рыболовной зоны России на Дальнем Востоке // Изв. ТИНРО. - 2002. - Т. 132. - С. 27-42.

Волков А.Ф. Биомасса, численность и размерная структура эвфаузиид северной части Охотского моря в весенний период 1998-2001 гг. // Изв. ТИНРО. - 2002. - Т. 130. - С. 336-354.

Волков А.Ф. Горизонтальная структура планктонного сообщества Карагинского залива // Биол. моря. - 1988. - № 4. - С. 19-24.

Волков А.Ф. Зоопланктон эпипелагиали дальневосточных морей: состав сообществ, межгодовая динамика, значение в питании нектона : дис. ... д-ра биол. наук (в форме науч. докл.). - Владивосток : ТИНРО-центр, 1996. — 70 с.

Волков А.Ф. Массовое появление Themisto libellula в северной части Берингова моря: «вторжение» или «вспышка»? // Изв. ТИНРО. — 2012а. — Т. 168. — С. 142-151.

Волков А.Ф. Результаты исследований зоопланктона Берингова моря по программе «NPAFC» (экспедиция BASIS). Часть 2. Западные районы. // Изв. ТИНРО. — 2012б. - Т. 170. - С. 151-171.

Волков А.Ф. Таблицы и графики по трофологии минтая западной части Берингова моря // Изв. ТИНРО. - 2016. - Т. 185. - С. 175-184.

Волков А.Ф., Ефимкин А.Я. Планктонные сообщества и кормовая база рыб эпипелагиали Берингова моря в осенний период // Изв. ТИНРО. — 1990. — Т. 111. — С. 94-102.

Волков А.Ф., Ефимкин А.Я., Кузнецова Н.А. Характеристика планктонного сообщества Берингова моря и некоторых районов северной части Тихого океана в период 2002-2006 гг. // Изв. ТИНРО. - 2007. - Т. 151. - С. 338-364.

Дриц А.В., Уткина С.В. Питание Sagitta setosa в слоях дневного скопления планктона в Черном море // Океанол. - 1988. - № 6. - С. 1014-1020.

Дробышева С.С. Эвфаузииды Баренцева моря и их роль в формировании промысловой биопродукции : моногр. - Мурманск : ПИНРО, 1994. - 139 с.

Дулепова Е.П. Динамика продукционных показателей зоопланктона как основы кормовой базы нектона в западной части Берингова моря // Изв. ТИНРО. — 2014. — Т. 174. - С. 236-249.

Дулепова Е.П. Динамика структурно-функциональных характеристик планктонных сообществ западной части Берингова моря в 2000-х гг. // Вопр. рыб-ва. — 2005. - Т. 6, № 2(22). - С. 256-277.

Дулепова Е.П. Планктонное сообщество эпипелагиали западной части Берингова моря: состав, продуктивность и сезонная динамика // Экология моря. — 1993. — Вып. 44. — С. 8-15.

Дулепова Е.П. Сравнительная биопродуктивность макроэкосистем дальневосточных морей : моногр. - Владивосток : ТИНРО-центр, 2002. — 273 с.

Иванова М.Б. Продукция планктонных ракообразных в пресных водах : моногр. — Л. : ЗИН АН СССР, 1985. - $220 \mathrm{c.}$

Косихина О.В. Исследование питания Chaetognatha // Экология моря. - 1982. - Вып. 11. - C. 79-83.

Маркина Н.П., Хен Г.В. Основные элементы функционирования пелагических сообществ Берингова моря // Изв. ТИНРО. — 1990. — Т. 111. — С. 79-93.

Одум Ю. Основы экологии : моногр. - М. : Мир, 1975. — 740 с.

Орлова Э.Л., Зайцева К.А., Яковлев А.П. Климат и изменчивость видового состава эвфаузиид Баренцева моря // Вестн. МГТУ. — 2012. - Т. 15, № 4. - С. 827-832.

Рекомендации по экспресс-обработке сетного планктона в море / А.Ф. Волков. Владивосток : ТИНРО, 1984. - $31 \mathrm{c.}$

Сапожников В.В. Комплексные экологические исследования экосистем Берингова и Охотского морей // Океанол. - 1994. - Т. 34, № 2. - С. 309-312.

Степаненко М.А., Грицай Е.В. Состояние ресурсов, условия обитания и промысел минтая в восточной и северо-западной частях Берингова моря в начале 2010-х годов // Вопр. рыб-ва. — 2013. - Т. 14, № 2. - С. 219-241. 
Чучукало В.И., Шебанова М.А., Дулепова Е.П., Горбатенко К.М. Жизненные циклы, соматическая продукция эвфаузиид в Охотском море // Изв. ТИНРО. — 2013. - Т. 173. — С. 164-183.

Шебанова М.А. Продукция некоторых массовых видов копепод в Охотском море в летнеосенний период // Изв. ТИНРО. — 2007. — Т. 148. — С. 221-237.

Шебанова М.А. Соматическая продукция и жизненные циклы сагитты Parasagitta elegans в Охотском и Беринговом морях // Актуальные проблемы освоения биологических ресурсов Мирового океана : мат-лы 4-й междунар. науч.-техн. конф. - Владивосток : Дальрыбвтуз, 2016. - Ч. 1. - С. 218-223.

Шебанова М.А., Чучукало В.И., Горбатенко К.М. Жизненные циклы, соматическая продукция гипериид в Охотском и Беринговом морях // Изв. ТИНРО. - 2014. - Т. 176. — С. 155-176.

Шунтов В.П. Биология дальневосточных морей России : моногр. - Владивосток : ТИНРО-центр, 2001. - Т. 1. - 580 с.

Шунтов В.П. Почему изменяется численность минтая (Theragra chalcogramma) // Изв. ТИНРО. - 2016. - Т. 185. - С. 31-48.

Шунтов В.П., Волков А.Ф., Темных О.С., Дулепова Е.П. Минтай в экосистемах дальневосточных морей : моногр. - Владивосток : ТИНРО, 1993. - 426 с.

Шунтов В.П., Дулепова Е.П. Современное состояние, био- и рыбопродуктивность экосистемы Берингова моря // Комплексные исследования экосистемы Берингова моря. - М. : ВНИРО, 1995. - С. 358-388.

Шунтов В.П., Дулепова Е.П., Горбатенко К.М. и др. Питание минтая Theragra chalcogramma в анадырско-наваринском районе Берингова моря // Вопр. ихтиол. - 2000. - Т. 40, № 3. - С. 362-369.

Шунтов В.П., Дулепова Е.П., Темных О.С. и др. Состояние биологических ресурсов в связи с динамикой макроэкосистем в экономической зоне дальневосточных морей России // Динамика экосистем и современные проблемы сохранения биоресурсного потенциала морей России. - Владивосток : Дальнаука, 2007. - С. 75-176.

Шунтов В.П., Темных О.С., Найденко С.В. и др. К обоснованию экологической емкости дальневосточных морей и субарктической Пацифики для пастбищного выращивания тихоокеанских лососей. Сообщение 4. Влияние фактора плотности на обеспеченность тихоокеанских лососей пищей и их роль в потреблении кормовой базы нектона // Изв. ТИНРО. - 2010. — Т. 161. - C. 25-52.

Dalpadado P., Skjoldal H.R. Distribution and life history of krill from the Barents Sea // Polar Res. - 1991. - Vol. 10. — P. 443-460.

Fraser J.H. Experimental feeding of some Medusa and Chaetognatha // J. Fish. Bd Canada. 1969. - Vol. 26, № 7. - P. 1743-1762.

Khen G.V., Basyuk E.O., Vanin N.S., Matveev V.I. Hydrography and biological resources in the western Bering Sea // Deep-Sea Res. II. - 2013. — Vol. 94. — P. 106-120.

Поступила в редакичюю 3.10.16 г. 